\title{
Sensory analysis of Creole turkey meat with flash profile method
}

\author{
Emmanuel de Jesús Ramírez-Rivera ${ }^{1}$, Marco Antonio Camacho-Escobar², \\ Juan Carlos García-López ${ }^{3}$, Virginia Reyes-Borques ${ }^{2}$, Mabel Rodríguez-Delatorre ${ }^{2}$ \\ ${ }^{1}$ Laboratorio de Alimentos, Universidad del Mar Campus Puerto Ángel, Pochutla, México \\ ${ }^{2}$ Instituto de Industrias, Universidad del Mar, Campus Puerto Escondido, Mixtepec, México; \\ *Corresponding Author: marcama@zicatela.umar.mx \\ ${ }^{3}$ Instituto de Investigación de Zonas Desérticas, Universidad Autónoma de San Luis Potosí, San Luis Potosí, México
}

Received 19 November 2011; revised 25 December 2011; accepted 3 January 2012

\begin{abstract}
Different kind of feed can result in development of new meat odors, aroma and texture. The aim of the study was to use flash profile method to determine differences; if any, in sensory traits of Creole turkey meat with different alimentation programs. Treatments were kitchen leftovers + fresh forage, commercial feed, kitchen leftovers, commercial feed + fresh forage, and broken maize + fresh forage. Cooked thighs, drumstick and breast were used. For the meat evaluation two different groups of people were recruited. In order to perform the sensory profile of breast six persons were recruited, in a second group nine persons; in both cases they did not know what kind of meat they were evaluating. Each sensory profile had three replicas, previously three training sessions and establishment of sensory attributes criteria were held. Attribute discrimination was evaluated one-way ANOVA. To obtain consensus and treatment mean position, attributes of the subjects a Generalized Procrustes Analysis was used and comparison of treatments through an ascendant hierarchy classification. Thirty five different sensory descriptive were generated. There were differences in meat sensory profile, it can be said that different treatments influenced in different ways the muscle development of Creole turkey, creating new sensory attributes.
\end{abstract}

Keywords: Backyard; Feed System; Forage; Guajolote; Kitchen Leftovers

\section{INTRODUCTION}

Backyard turkey production is very important in Méxi- co and Central America as an economic and cultural issue; for instance, in the Coast of Oaxaca this kind of production represents the main source of income for rural families [1]. An important attribute given by consumers to Creole turkey meat is that the meat has a better taste than the commercial turkeys [2]. In backyard turkey production there are several factors that affect the final presentation of the meat and can have a negative impact in the final quality; one of them is the type of feed used for these animals [3]. It has been reported that when different ingredients are present in the feed, turns out in meat sensory differences [4], such differences are attributed to quantity; composition and distribution of inter muscle fat [5].

Traditionally different sensory traits techniques have been used for poultry products [3], nowadays there are diverse rapid methods of characterization, with the goal to investigate sensory differences between products, and such methods are performed before market analysis and the impact of a new ingredient [6]. Several descriptive techniques has been used such as the flavor profile [7], texture profile [8], quantitative descriptive analysis (QDA) methodology [9], the Spectrum method [10]; however, to apply anyone of the above methods, it is required long lasting exhaustive sessions of training of assessors, in order to provide reliable and consistent results [6].

Recently a merge was performed of the free choice profiling (FCP) [11] with the ranking method on simultaneous presentation of the whole product set, such combination is called the flash profile (FP) [6], where each subject chooses and uses his/her own words to evaluate the whole product set comparatively, this eliminate the large training sessions and getting data for a rapid analysis $[12,13]$.

Nowadays, the flash profile has been used in diverse investigations for sensory descriptive in jams, strawberry yogurt [6], texture evaluation of apple mash [14], for sensory instrumental correlation of baked products [15]. 
To date there are no previous reports of the use of flash profile in the evaluation of poultry products, despite their evident advantages. The aim of this study was to use the flash profile to determine if there were meat sensory traits differences in backyard Creole turkeys under two different feed programs.

\section{MATERIALS AND METHODS}

\subsection{General Procedure}

Sensory evaluation was held in a school dinner room in the city of Puerto Escondido, Oaxaca, México, meat samples were prepared in the kitchen. Panelists were trained in a classroom and then started the evaluation in partitioned booths without contact with the rest of the panelist. The evaluation procedure started at 09:00 $\mathrm{h}$ with a room temperature $24^{\circ} \mathrm{C}$. Meat was from Creole turkeys were bought in the Coast of Oaxaca from turkey backyard producers raised from fourth months old during a period of fifteen months in the experimental camp of the Universidad del Mar under commercial intensive system. Experimental treatments were planned to simulate the kind of feed given to Creole turkey in the backyard [16]. The following treatments were tested 1) kitchen leftovers + fresh forage, 2) turkey commercial feed, 3) kitchen leftovers, 4) turkey commercial feed + fresh forage, and 5) broken maize + fresh forage. Kitchen leftovers contain a variety of feed in a good status conservation: such as rice, beans, tortilla, oat, bread or flour wheat products, raw tomato, lettuce leafs, cabbage, broccoli, beet, carrots, corn, peas, occasionally apple, pear, papaya, watermelon, egg, beef meat, chicken, fish, milk, cheese, turkey and pork sausage. Kitchen leftovers were offered to turkeys in trays, broken maize and commercial feed in feeders, and bunch of fresh forage.

Turkey were slaughter by cervical dislocation, in Universidad del Mar slaughterhouse, they were immediately bled, feathers were took off rinse out with water at $60^{\circ} \mathrm{C}$ during two minutes, the offal were removed, carcass was cut in pieces, meat skin and fat was removed and deboned, then meat pieces were packed, individually labeled and frozen at $-20 \mathrm{C}$ during $30 \mathrm{~d}$. The meat samples used in this trial were from Pectoralis major and Pectoralis minor from white meat, as extensor and flexor muscles from anterior and posterior thigh, and muscles Gastrocnemio pars lateralis, intermedia and medialis from right drumstick, which represent red meat cut in Creole turkeys.

For the flash profile (FP) assessment each sample from each treatment were coded using 3-digit random numbers (Table 1) to avoid the halo effect in the meat samples at the moment to be evaluated [17]. Creole turkey meats was cooked in boiling water at $100^{\circ} \mathrm{C}$ until reach a core temperature of $76^{\circ} \mathrm{C}$, and then sit for at least
Table 1. Diets for Creole turkeys and codes of meat experimental treatments.

\begin{tabular}{lccc}
\hline \multirow{2}{*}{$\begin{array}{c}\text { Type of } \\
\text { feeding }\end{array}$} & Treatment & $\begin{array}{c}\text { Flash Profile White } \\
\text { Muscle }^{1}\end{array}$ & $\begin{array}{c}\text { Flash Profile Red } \\
\text { Muscle }^{2}\end{array}$ \\
\cline { 3 - 4 } & 1 & Code & Code \\
\hline $\mathrm{KL}^{3}+\mathrm{FF}^{4}$ & 2 & IFB & O25 \\
$\mathrm{CF}^{5}$ & $6 \mathrm{IE}$ & FDR \\
$\mathrm{KL}$ & 3 & PZG & GI4 \\
$\mathrm{CF}+\mathrm{FF}$ & 4 & $\mathrm{U} 5 \mathrm{~W}$ & DMW \\
$\mathrm{BM}^{6}+\mathrm{FF}$ & 5 & $\mathrm{~N} 30$ & 3BG \\
\hline
\end{tabular}

${ }^{1}$ Breast muscle of Creole Turkey; ${ }^{2}$ Thigh and Drumstick of Creole Turkey; ${ }^{3}$ Kitchen leftovers; ${ }^{4}$ Fresh forage; ${ }^{5}$ Commercial feed; ${ }^{6}$ Broken Maize.

$6 \mathrm{~h}$ before the test, in each sensory test, each panelist was offered $10 \mathrm{~g}$ of each product, at a $20^{\circ} \mathrm{C} \pm 1^{\circ} \mathrm{C}$.

\subsection{Flash Profile procedure}

The Flash Profile procedure was based in the work developed by Dairou and Sieffermann [18]; in order to evaluate the two different types of turkey Creole meat (white and red), two different groups of people were recruited to assesses; the first group breast meat (white) and the second group, thigh and drumstick (red). To perform the first sensory profile, six subjects were recruited (4 women and 2 men) which did not know the kind of meat they were going to assess (white meat); the second group with nine assessors ( 4 women and 5 men) for the red meat. Assessors were college students with age ranged 20 - 40 years old.

Each sensory profile had three replicas distributed in same session number, previously three sessions of training were held to establish sensory attribute criteria. In the first session, subjects recruited were trained with basic concepts of sensory analysis, such as attribute extraction and measure scale; also the flash profile concept was explained, the session last one hour [17].

In the second session, each assessor generated an individual and provisional list of sensory attributes, which in turn with this attribute would be able to differentiate the samples, then the attributes were classified in appearance, texture, odor, taste and aroma categories; session last around $45 \mathrm{~min}$.

During the third session the assessors selected final sensory attributes and determine the individual final list; each one of the generated attribute list by the assessors was compared with the list of the rest of the group, this session last around $30 \mathrm{~min}$.

In the fourth, fifth and sixth session the sensory evaluation of samples was performed, all simples were presented simultaneously to all assessors, each one of the sensory attributes was scored on an ordinal scale from 0 to 10 . These sessions last around $1 \mathrm{~h}$, resting $60 \mathrm{~min}$ between every session, in order to avoid influence effect 
[17]. During the tests, panelists rinsed their mouth with water between samples [19].

\subsection{Statistical Analysis}

Attribute discrimination by each subject was evaluated by a one-way analysis of variance (ANOVA), considering type of feed as the factor. A consensus configuration for the flash profile data was provided by a Generalized Procrustes Analysis (GPA) [12,14]; then the classification of the evaluated treatments was compared by the two subject groups through Ascendant Hierarchy Classification (AHC). Statistical treatment of sensory data was done by Statgraphic [20] for the ANOVA, for GPA and AHC the program XLSTAT ${ }^{\circledR}$ by Microsoft Excel $^{\circledR}$ version 7.5 [21].

\section{RESULTS AND DISCUSSION}

For the first flash profile, where white meat was evaluated (breast) the group of assessors generated a rank between 5 and 19 attributes each, to obtain a total of 35 different sensory descriptors (Table 2).
In the second flash profile, where red meat was evaluated (thigh and drumstick) the assessors created between 4 and 19 attributes for a total of 35 different sensory descriptors (Table 3). Tables 2 and $\mathbf{3}$ show the ANOVA results for each generated attribute by assessors in both types of meat, attributes shows in bold letters are the most important since they contributed to the sensory differentiation of the meat with the different types of feed $(\mathrm{P}<0.05)$.

\subsection{Sample Sensory Description}

Figures 1 and $\mathbf{2}$ show the sensory map of white Creole turkey meat (breast) obtained by flash profile 1. Figure 1 graphically represents the sensory differentiation of feed treatments, treatments 2 and 3 (commercial feed and kitchen leftovers) form a group with common sensory characteristics, while treatments 1 and 4 (kitchen leftovers + fresh forage and commercial feed + fresh forage) are in opposition to the principal axes, which indicates that such treatments produced meat with distinctive sensory attributes to the other treatments. Treatment 5 (broken

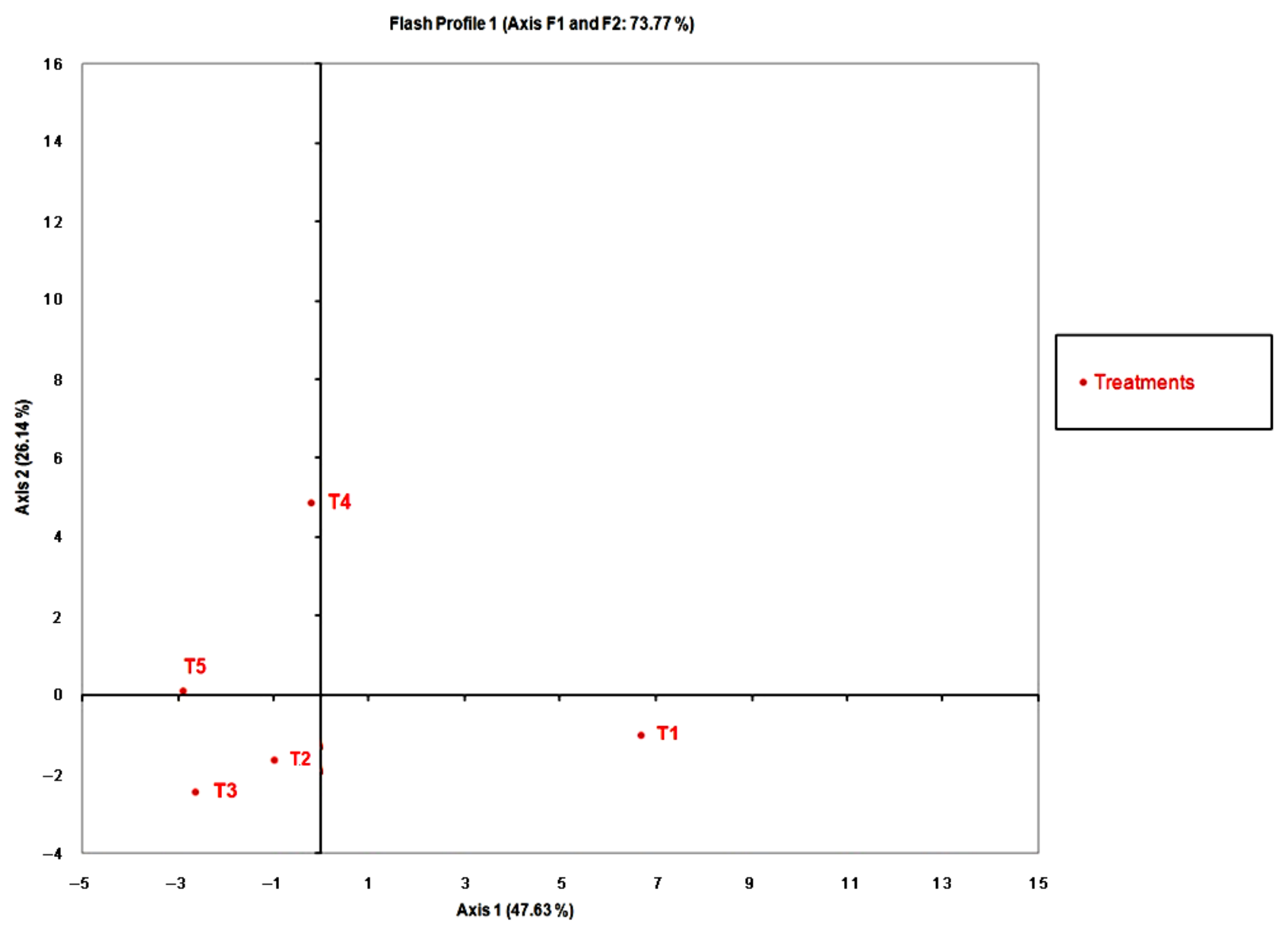

Figure 1. Representation of Creole turkey meat sensory position with different diets. $\mathrm{T} 1=$ kitchen leftovers + fresh forage, $\mathrm{T} 2=$ commercial feed, $\mathrm{T} 3=$ kitchen leftovers, $\mathrm{T} 4=$ commercial feed + fresh forage; $\mathrm{T} 5=$ broken maize + fresh forage. 
Table 2. Probability of descriptors for the assessors for the flash profile sensory test with Creole white turkey meat samples (breast).

\begin{tabular}{|c|c|c|c|c|c|c|}
\hline \multirow{2}{*}{ Attribute } & \multicolumn{6}{|c|}{ Judge } \\
\hline & 1 & 2 & 3 & 4 & 5 & 6 \\
\hline Garlic Aroma & 0.156 & & & & & \\
\hline Chicken Aroma & 0.312 & & & & & 0.037 \\
\hline Fish Aroma & & & 0.372 & & & 0.056 \\
\hline Spicy Aroma & & & & 0.270 & & \\
\hline Fat Aroma & & & & & & 0.017 \\
\hline Salty Flavor & 0.974 & 0.249 & & & & \\
\hline Acid Flavor & 0.535 & & & & & \\
\hline Sweet Flavor & & & & & & 0.029 \\
\hline Fish Odor & 0.093 & & 0.443 & & & 0.004 \\
\hline Onion Odor & & 0.168 & & & & \\
\hline Chicken Odor & & & & 0.376 & 0.807 & 0.392 \\
\hline Pork Odor & & & & 0.997 & & \\
\hline Sweet Odor & & & & & & 0.133 \\
\hline Porous & 0.367 & & & & & \\
\hline Juicy & 0.150 & & 0.858 & & & 0.036 \\
\hline Smooth to tact & 0.112 & 0.059 & 0.725 & 0.288 & 0.938 & \\
\hline Shred & 0.771 & 0.280 & 0.382 & & 0.124 & 0.030 \\
\hline Elasticity & & & & 0.226 & & \\
\hline Firmness & & & & 0.417 & & \\
\hline Hardness & & & & & & 0.060 \\
\hline Dry & 0.773 & & & & & \\
\hline Sticky & & 0.700 & 0.782 & & 0.376 & \\
\hline Crumble & & & & & 0.445 & \\
\hline Compact & & & & 0.398 & & \\
\hline Humid to mouth & & 0.389 & & 0.118 & & 0.063 \\
\hline Firm to mouth & & & & 0.315 & & \\
\hline Smooth to mouth & & & & 0.027 & & 0.005 \\
\hline Juicy to mouth & & & & & & 0.037 \\
\hline Humid to mouth & & & & & & 0.010 \\
\hline Hard to mouth & & & & & & 0.026 \\
\hline Brown Color & & & 0.352 & & & \\
\hline Yellow Color & & & & 0.053 & & 0.142 \\
\hline White Color & & & & & & 0.405 \\
\hline Porous to view & & & & & & 0.002 \\
\hline Stringy to view & & & & & & 0.667 \\
\hline
\end{tabular}

maize + fresh forage) in opposition to the group of samples 1 and 2 by axes 1 and in opposition to samples 1 and 4 (Figure 1).

Spatial distribution of each of the sensory attributes of white meat according to the sensory description of assessors is shown in Figure 2. It can be seen that white meat from treatment with kitchen leftovers + fresh forage had a higher intensity of chicken odor, fish odor, salty, sticky, shred and very smooth to tact; while, the white meat with the treatment with commercial feed (control), by its position near to origin, was characterized like a typical product; however, it was more sticky in the mouth than the other treatments; white meat from turkey fed with kitchen leftovers was perceived as a dry product, acid taste, shred and hard in mouth; while white meat from turkeys fed with commercial feed and fresh forage was perceived as a grease product, with spice aroma, garlic, chicken and pig (Figure 2). The most quantity of sensory attributes described for white meat where found in treatments 1 and 4 (kitchen leftovers + fresh forage and commercial feed + fresh forage).

Figures $\mathbf{3}$ and $\mathbf{4}$ show the flash profile 2 results, where red turkey meat (thigh and drumstick) was evaluated. Regarding feed treatment of Creole turkeys in 1 and 2 axes, it can be seen $67.90 \%$ of total data variation. Products 1 and 3 (kitchen leftovers + fresh forage and kitchen leftovers) are differentiated to the rest of treatments and are separated by the second axes in opposition to products 2, 4 and 5 (commercial feed, commercial feed + fresh forage and broken maize + fresh forage) Figure 3.

Creole red turkey meat fed with kitchen leftovers + fresh forage had a brown color, smooth to the tact and the mouth, sweet odor and aroma and odor to turkey meat. Thigh and drumstick meat from turkeys fed with commercial feed was tender in the mouth, porous and juicier. Turkeys fed with kitchen leftovers had red meat which was sweet, was steadier, metal and chicken aroma, usually found in blood. When feeding turkeys with commercial feed + fresh forage, red meat had meat odor, chicken and pork aroma, and to be more sticky. Treatment with broken maize + fresh forage made the thigh and drumstick as salad and had an aroma and odor like a smoked product (Figure 4). Same as breast white meat, assessors perceived the most quantity of sensory attributes on treatments 1 and 4 (kitchen leftovers + fresh forage and commercial feed + fresh forage), which implies that both treatments provide different desirable traits for consumers on Creole turkey meat (red and white), the other treatments granted few sensory attributes, not very diverse.

\subsection{Comparison of Product Classification}

Ascendant hierarchy classification reveal that turkey meat fed with different diets, were classified in a similar way (Figures 5 and 6); however, there were higher differences in the red meat profile from turkeys fed commercial feed and kitchen leftovers, moreover, there were higher number of similar traits in turkeys fed with commercial feed + fresh forage and broken maize + fresh forage, which are located in different way in the white meat profile; therefore, in can be deduced that the different diets used for the turkeys, have a different impact in the muscle development of the bird, giving new sensory attributes, that make the differences perceived in the evaluated meat. 
Table 3. Probability of descriptors for the assessors for the flash profile sensory test with Creole red turkey meat samples (thigh and drumstick).

\begin{tabular}{|c|c|c|c|c|c|c|c|c|c|}
\hline \multirow{2}{*}{ Attribute } & \multicolumn{9}{|c|}{ Judge } \\
\hline & 1 & 2 & 3 & 4 & 5 & 6 & 7 & 8 & 9 \\
\hline Sweet Flavor & & 0.462 & 0.001 & & & & & 0.014 & 0.242 \\
\hline Salty Flavor & & & & & 0.067 & & & & \\
\hline Chicken Aroma & 0.354 & & & & & 0.018 & & & \\
\hline Metallic Aroma & & & & & 0.202 & & & & \\
\hline Smoked Aroma & & & & & 0.892 & & & & \\
\hline Turkey Aroma & & & & & & & 0.087 & & \\
\hline Pork Aroma & & & & & & & 0.182 & & \\
\hline Chicken Odor & 0.590 & & & & & & & & \\
\hline Fish Odor & & & 0.129 & & & & & 0.080 & \\
\hline Turkey Odor & & & & & 0.296 & & & & \\
\hline Stringy Odor & & & & & 0.145 & & & & \\
\hline Smoked Odor & & & & & 0.699 & & & & 0.876 \\
\hline Sweet Odor & & & & & & & 0.358 & & 0.089 \\
\hline Sticky to tact & 0.547 & & & 0.079 & & & & 0.566 & \\
\hline Smooth to tact & & 0.594 & 0.044 & 0.035 & & & 0.19 & 0.709 & \\
\hline Rough to tact & & 0.037 & & & & & & & \\
\hline Firmness to tact & & & & 0.035 & 0.999 & 0.645 & & & 0.504 \\
\hline \multicolumn{10}{|l|}{ Humid to tact } \\
\hline Marbling to tact & & & & & & 0.195 & 0.294 & & \\
\hline Porous to tact & & & & & & & & & 0.691 \\
\hline Heavy & & & & & & & & & 0.860 \\
\hline Dry & & & & & & 0.796 & & & \\
\hline Firm to mouth & & & & & 0.052 & & & & \\
\hline Smooth to mouth & & & & 0.204 & & & & & 0.469 \\
\hline Rough to mouth & & & & 0.144 & & & & & \\
\hline Juicy to mouth & & & & & & 0.002 & & & 0.035 \\
\hline Dough in mouth & & & & & & & & 0.762 & \\
\hline Fresh & & & 0.915 & & & & & & \\
\hline Crumble & & & & & 0.124 & 0.004 & & & 0.196 \\
\hline Brown Color & 0.624 & 0.570 & & 0.432 & 0.071 & 0.005 & 0.139 & 0.398 & \\
\hline Light Brown & & & 0.742 & & & & & & \\
\hline Translucent & & & & & & & & & 0.009 \\
\hline Dry to view & & & & & 0.015 & & & & \\
\hline Rough to view & & & & & 0.014 & 0.001 & & & \\
\hline Symmetric to view & & & & & & & & & 0.456 \\
\hline
\end{tabular}

\subsection{Evaluation of Assessor's Performance}

Figures 7 and 8 shows the assessors used in the sensory description of red and white meat profile, respecttively, it can be seen that they make diverse groups around the breast meat products, assessor 7 was more remote than the others. For the thigh-drumstick evaluation, flash profile 2, assessors 2 and 6 are more remote from the group for treatments kitchen leftovers and commercial feed + fresh forage, assessor 9 was more remote for broken maize + fresh forage. Possible causes of the distance are the different terminology used by the assessors to describe the samples.

Flash profile has been used with success in pork meat sensory evaluation [18] and dairy products [6], in the present study the results are consistent in the sensory differentiation that acquires turkey meat with the intake of kitchen leftovers + fresh forage and commercial feed + fresh forage, that is why the group of assessors were able to perceive in a sensory way the meat of the different feeding treatments and to select them in a appropriate way. This sensory traits differentiation can be due to composition and quantity of intra muscle fat in the turkey 


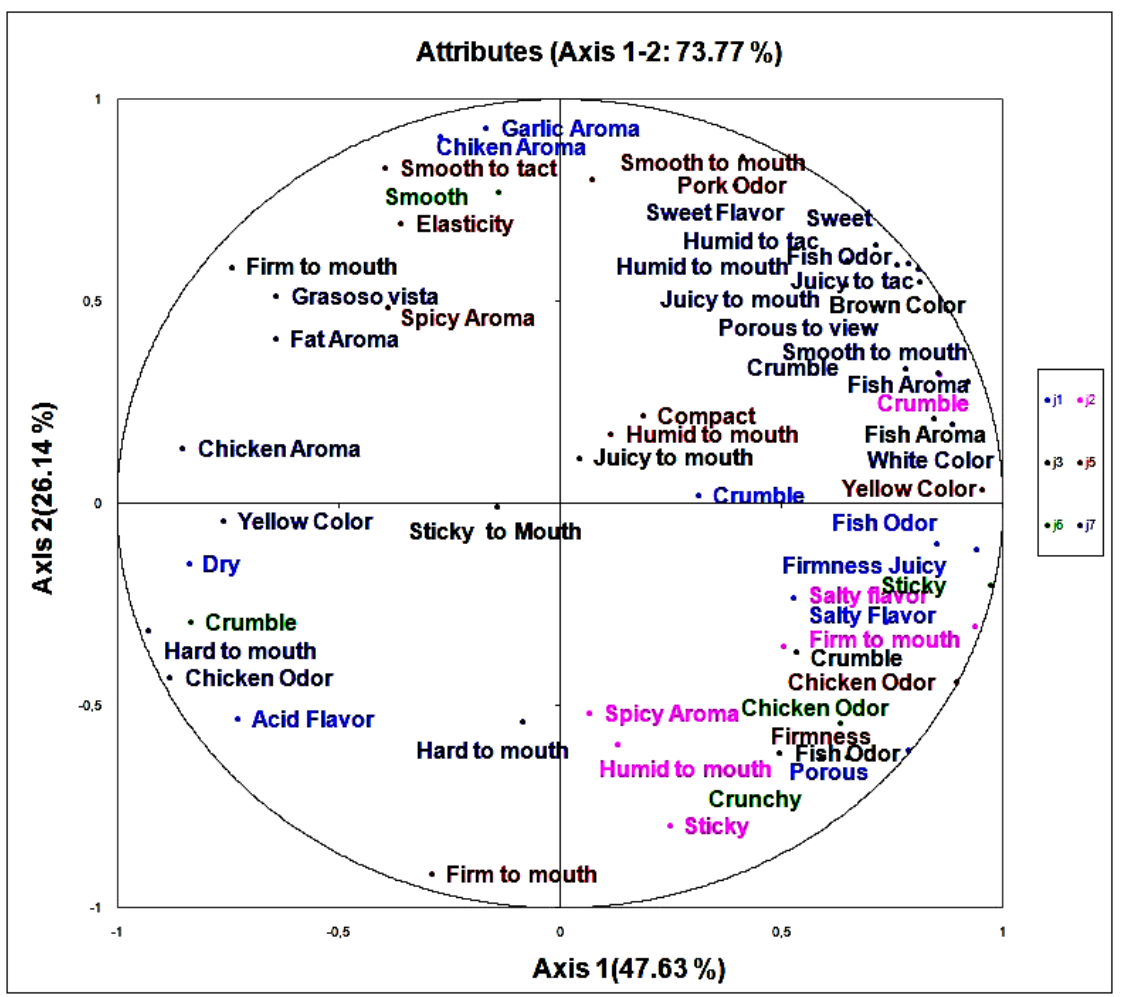

Figure 2. Representation of sensory attributes position of Creole white turkey meat defined by the two first dimensions consensus configuration.

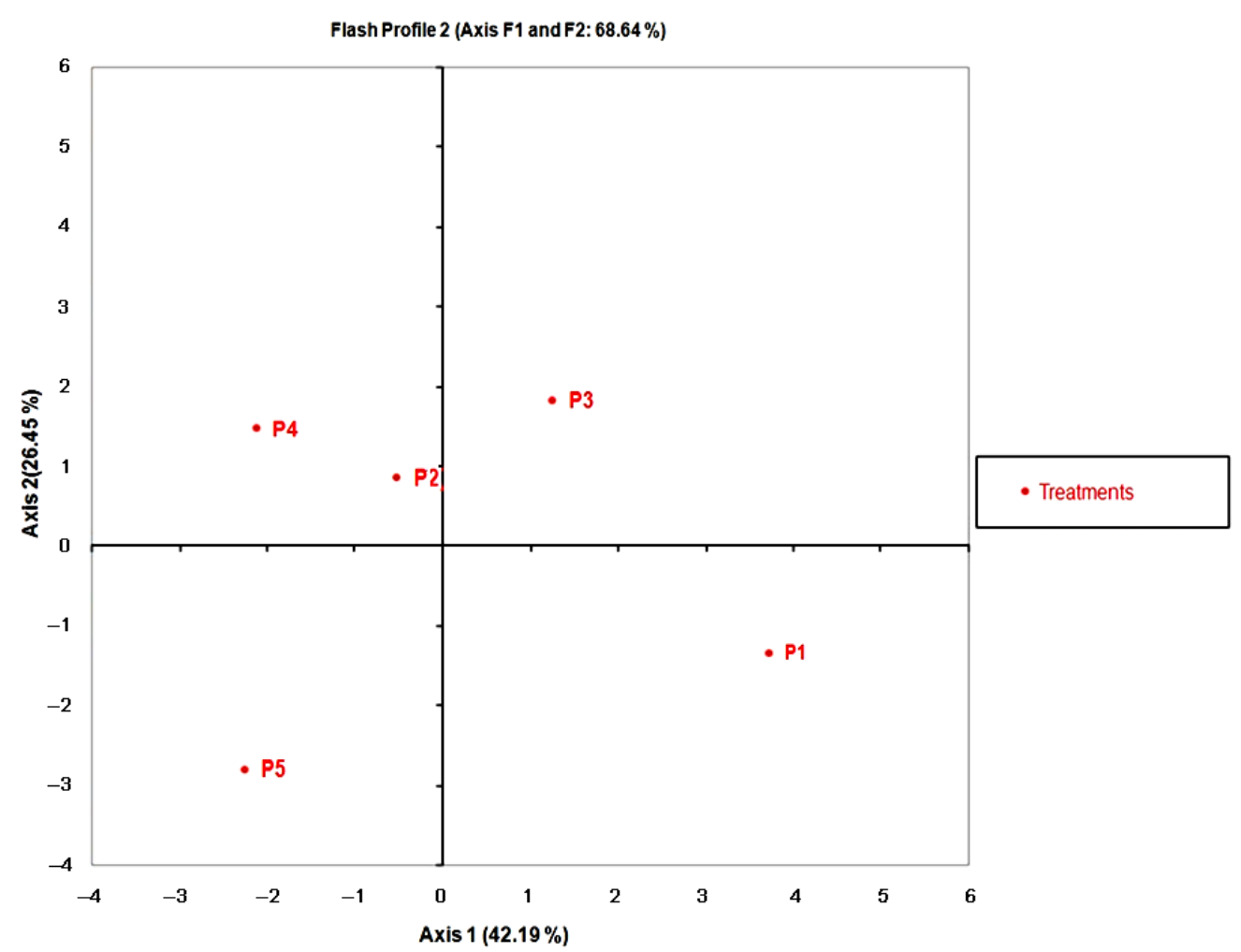

Figure 3. Representation of sensory attributes position of Creole red turkey meat with different diets. T1 = kitchen leftovers + fresh forage, $\mathrm{T} 2$ = commercial feed, $\mathrm{T} 3=$ kitchen leftovers, $\mathrm{T} 4$ = commercial feed + fresh forage; $\mathrm{T} 5$ = broken maize + fresh forage. 


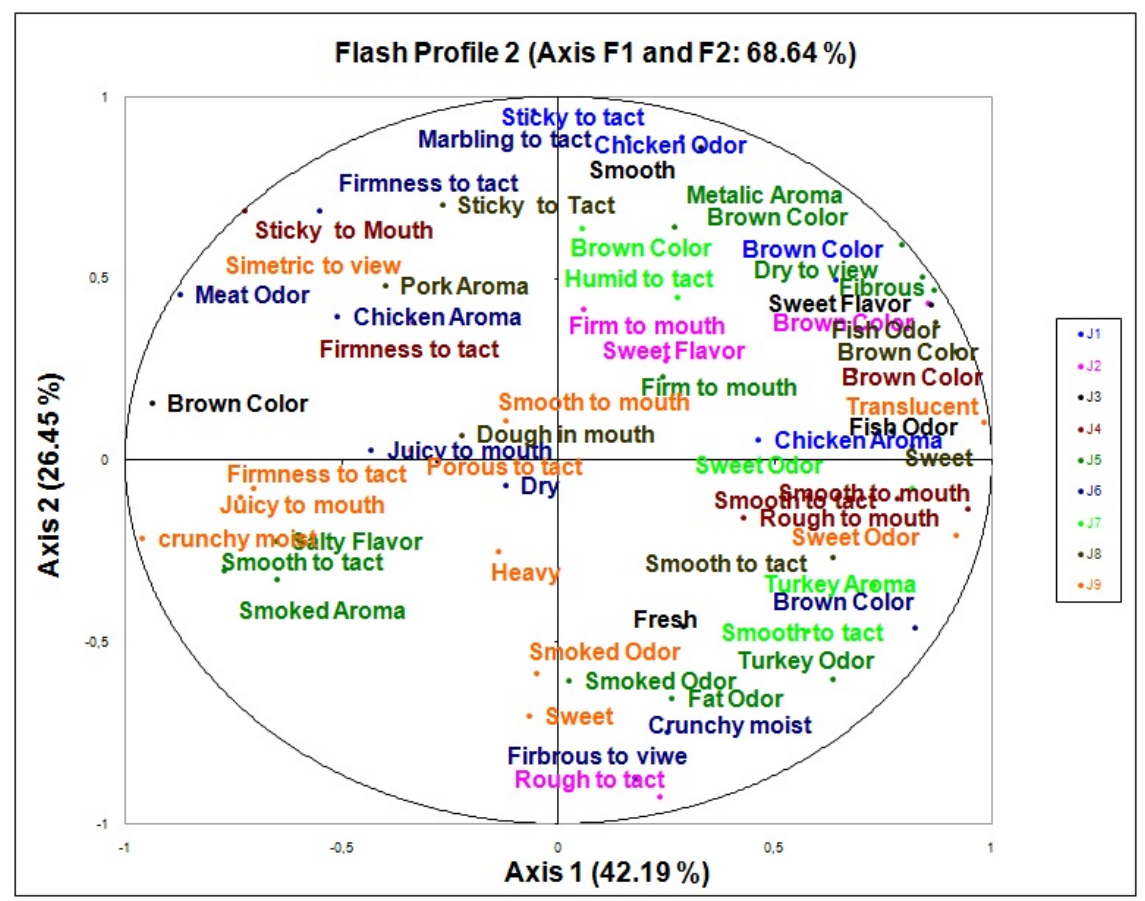

Figure 4. Representation of sensory attributes position of Creole red turkey meat defined by the two first dimensions consensus configuration.

Flash Profile 1

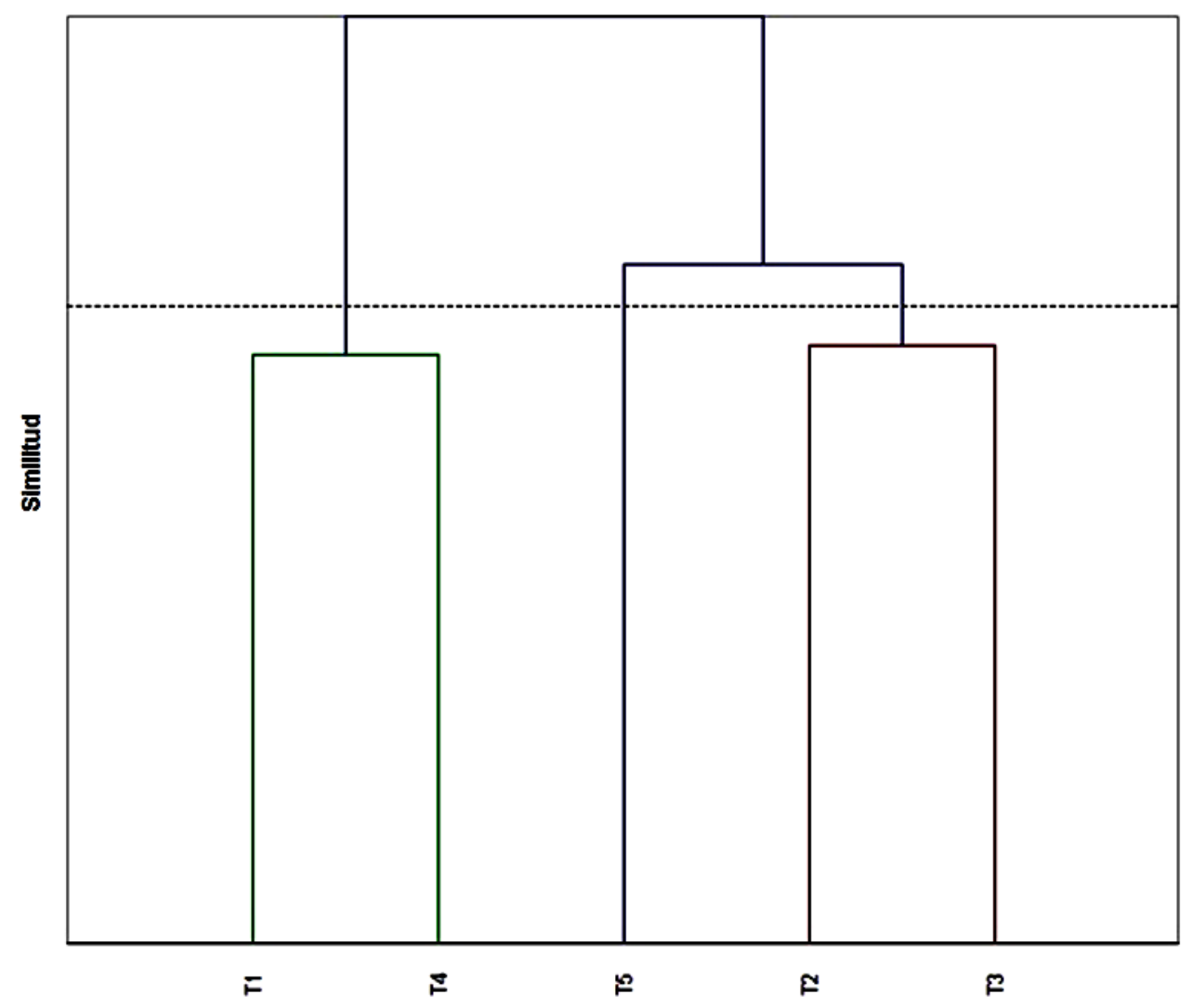

Figure 5. Ascendant hierarchy classification of sensory evaluation of Creole white turkey meat by flash profile method. 


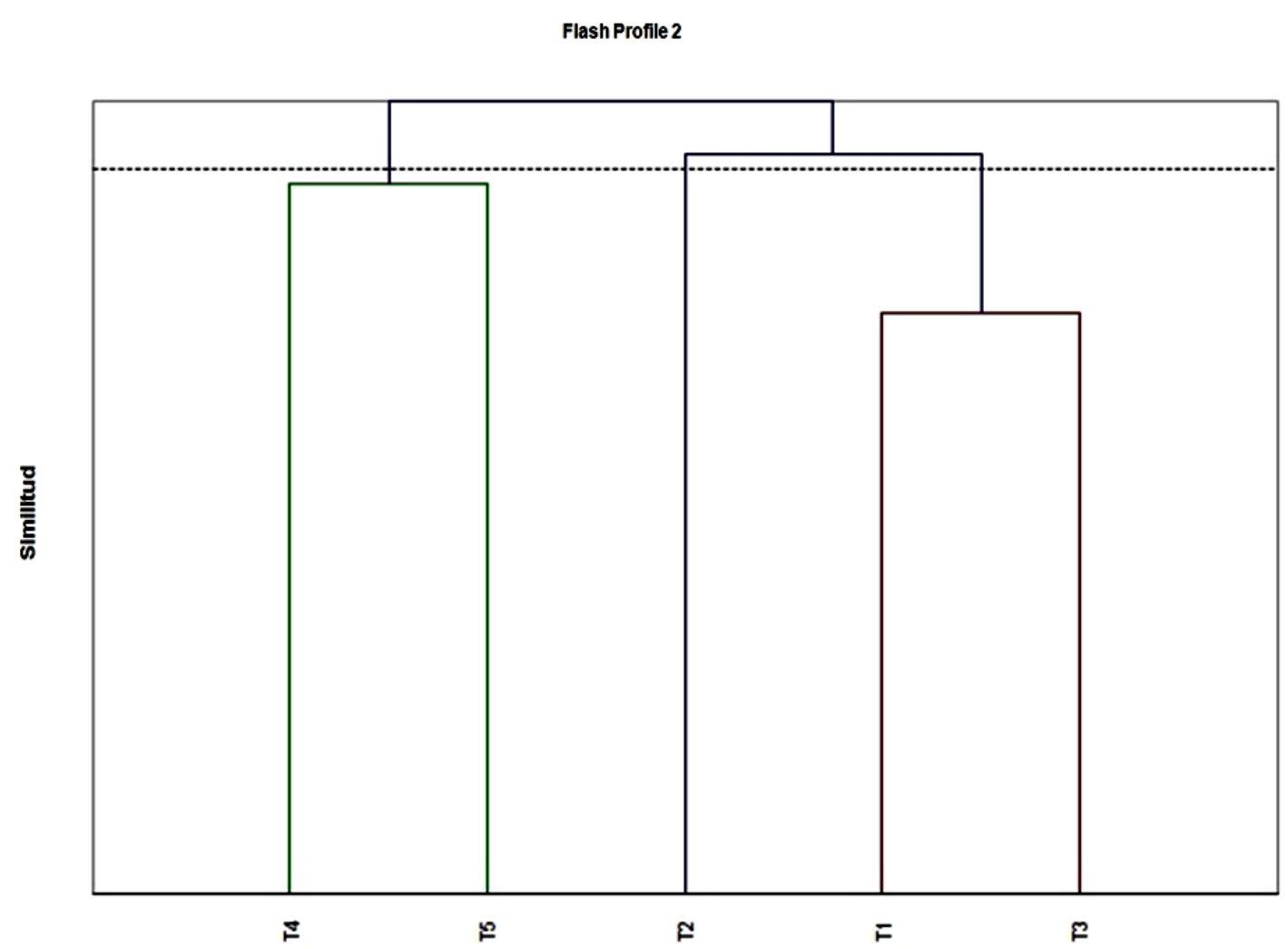

Figure 6. Ascendant hierarchy classification of sensory evaluation of Creole red turkey meat by flash profile method.

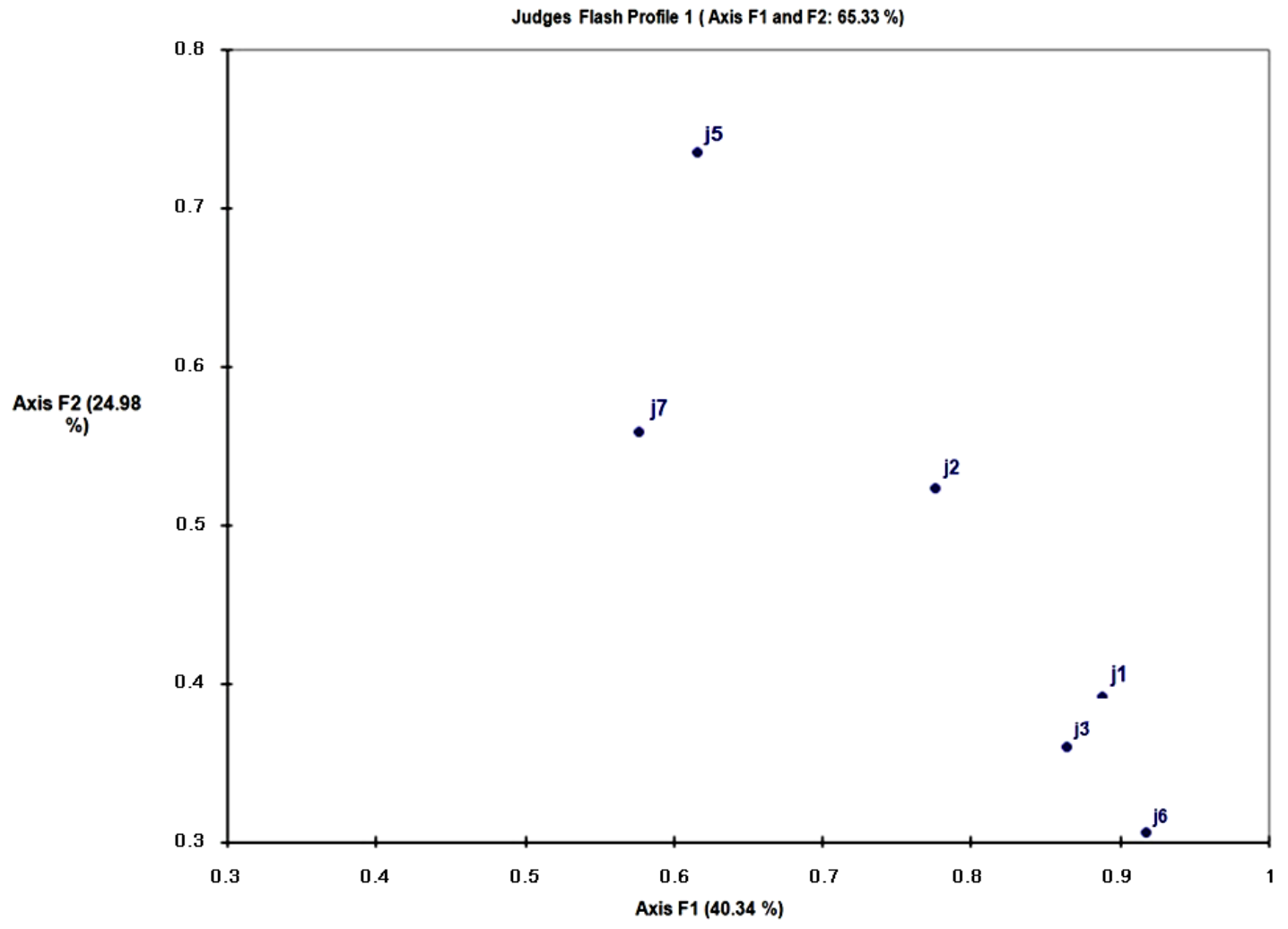

Figure 7. Creole red turkey meat assessor’s by flash profile method performance. 


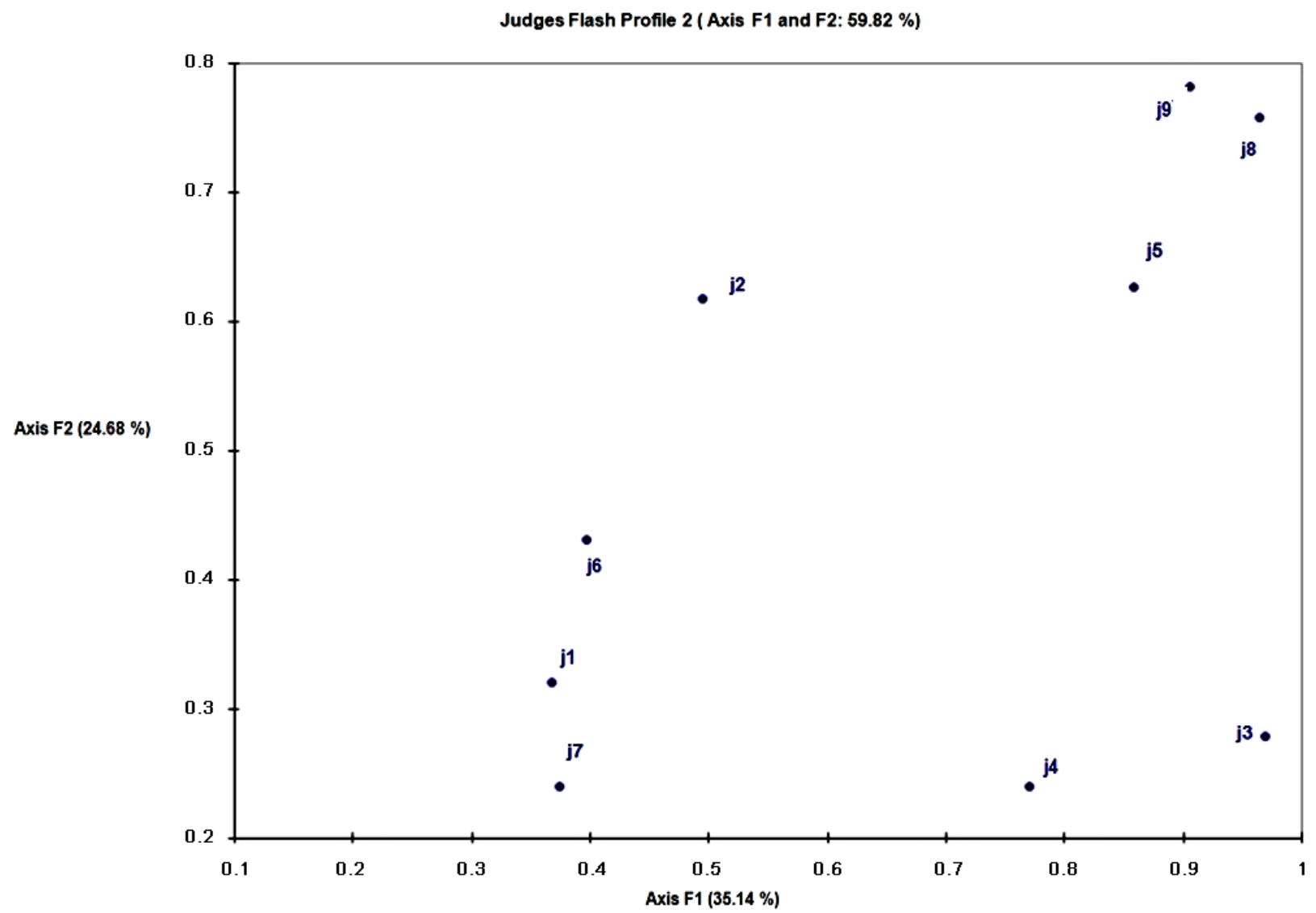

Figure 8. Creole red turkey meat assessor's by flash profile method performance.

meat [5] which varies depending on the type of feed or vitamin contribution [22] or additives such as $\beta$-carotene [23]; other ingredients such as rapeseed flour [24], yellow peas [25], yeast live culture [26] and triticale [27].

It is considered that sensory attributes are important criteria to be included at the moment of feeding animals, because it has an impact in the meat at the moment of consumer's choice in the market [28].

Several researchers have been looking for other causes that may affect sensory traits of birds meat, such as type of meat conservation, refrigerated or frozen [22], age, sex or feeding stage of the bird when is taken to slaughter [29], where they found inconsistence in the obtained results, more studies are warranted to clarify this issue. In the present study, the different diets used in backyard Creole turkeys had an effect on the development of new aromas, odors, colors and texture that contribute to quality sensory of red and white meat of Creole turkey. The diets kitchen leftovers + fresh forage and commercial feed + fresh forage, gave as a result new characteristic attributes to the turkey meat.

With the flash profile method it was evident in a quick way, the sensory attributes that make the difference between the white meat from breast and red meat from thigh and drumstick. The results from the present study show that flash profile is a reliable alternative of sensory characterization of Creole turkey meat, when there is not a trained sensory group available and without the proper sensory laboratory. The detected sensory attributes with the flash profile used in the present study can be used for the development of a sensory profile through quantitative descriptive analysis technique, as a basis to develop a consumer's preferences map and for the instrumentalsensory correlation.

\section{ACKNOWLEDGEMENTS}

The authors thank Yolanda García Bautista and "Estimulación Cognitiva Frida Kahlo A. C.” facilities and equipment to carry out this study.

\section{REFERENCES}

[1] Camacho-Escobar E.M.A., Lira, T.I., Ramírez, C.L., López, P.R. and Arcos, G.J.L. (2006) La avicultura de traspatio en la Costa de Oaxaca, México. Revista Ciencia y Mar, 10, 3-11.

[2] Hernández, S.V. (2006) Evaluación de los factores socioculturales, económicos y productivos de la crianza del guajolote doméstico en la región Costa de Oaxaca. Informe Final de Servicio Social Legal, Licenciatura en 
Medicina Veterinaria y Zootecnia, Universidad Autónoma Metropolitana.

[3] Poste, L.M. (1990) A sensory perspective of effects on flavor in meats: Poultry meats. Journal of Animal Science, 68, 4414-4420.

[4] Lyon, B., Smith, D., Lyon, C. and Savage, E. (2004) Effects of diet and fee withdrawal on the sensory descriptive and instrumental profiles of boiler breast fillets. Poultry Science, 83, 275-281.

[5] Chartrin, P., Méteau, K., Juin, H., Bernardet, M.D., Guy, G., Larzul, C., Remignon, H., Mourot, J., Duclos, M.J. and Baéza, E. (2006) Effects of intramuscular fat levels on sensory characteristics of duck breast meat. Poultry Science, 85, 914-922.

[6] DeLa Rue, J. and Siefferman, J. (2003) Sensory mapping using profile flash. Comparison with conventional descriptive method for the evaluation of flavor of fruit dairy products. Food Quality and Preferences, 15, 383-389. doi:10.1016/S0950-3293(03)00085-5

[7] Cairncross, S.E. and Sjostrom, L.B. (1950) Flavor profiles-A new approach to flavor problems. Food Technology, 4, 308-311.

[8] Brandt, M.A., Skuber, E. and Coleman, J. (1963) Texture profile method. Journal of Food Science, 28, 404-410. doi:10.1111/j.1365-2621.1963.tb00218.x

[9] Stone, H., Sidel, J., Oliver, S., Woosley, A. and Singleton, R.C. (1974) Sensory evaluation by quantitative descriptive analysis. Food Technology, 28, 24-34.

[10] Meilgaard, M., Civille, G.V. and Carr, B.T. (1999) Sensory evaluation techniques. 3rd Edition, CRC Press, Boca Raton. doi:10.1201/9781439832271

[11] Williams, A.A. and Arnold, G.M. (1985) A comparison of the aromas of 6 coffees characterized by conventional profiling, free-choice profiling, and similarity scaling methods. Journal of Sciences in Food Agriculture, 36, 204-214. doi:10.1002/jsfa.2740360311

[12] Gower, C.J. (1975) Generalized Procrustes Analysis. Psychometrika, 40, 33-51. doi:10.1007/BF02291478

[13] Qammari, M.E., Courcoux, P.H., Lejeune, M. and Maystre, O. (1997) Comparaison de trois de determination d' un compromis en évaluation sensorielle. Revue de Statisque Appliquée, 45, 61-74.

[14] Tarea, S., Civelier, G. and Sieffermann, J.M. (2007) Sensory Evaluation or the Texture of 49 Commercial Apple and Pear Purees. Journal of Food Quality, 30, 1121-1131. doi:10.1111/j.1745-4557.2007.00174.X

[15] Lassoued, N., DeLa Rue, J., Launay, B. and Michon, C. (2008) Baked product texture: Correlations instrumental and sensory characterization using Flash profile. Journal of Cereal Science, 48, 133-143. doi:10.1016/j.jcs.2007.08.014

[16] Camacho-Escobar, M.A., Hernández-Sánchez, V., Ramírez-Cancino, L., Sánchez-Bernal, E.I. and Arroyo-Ledezma, J. (2008) Characterization of backyard guajolotes (Meleagris gallopavo gallopavo) in tropical zones of
Mexico. Livestock Research for Rural Development, 20, Article \#50.

http://www.cipav.org.co/lrrd//rrd20/4/cama20050.htm

[17] Fortín, J. and Desplancke, C. (2001) Guía de selección y entrenamiento de un panel de catadores. ACRIBIA, España.

[18] Dairou, V. and Sieffermann, J.M. (2002) A comparison of 14 jams characterized by conventional profile and a quick original method, the Flash profile. Journal of Food Science, 67, 826-834. doi:10.1111/j.1365-2621.2002.tb10685.x

[19] Nogueira, H., Tinet, C., Curt, C. Trystram, G. and Hossenlop, J. (2006) Using the internet for descriptive sensory analysis: Formation, training and follow-up a taste-test panel over the web. Journal of Sensory Studies, 21, 180-202. doi:10.1111/j.1745-459X.2006.00060.x

[20] Statgraphics plus Software Version 5.1. (1994) Statistical Graphics Corporation, Warrenton, VA.

[21] XLSTAT ${ }^{\circledR}$ for Microsoft Excel ${ }^{\circledR}$ version 7.5. (2005) Microsoft Corp., Redmond, Washington DC.

[22] Sheldon, B.W., Curtis, P.A., Dawson, P.L. and Ferket, P.R. (1997) Effect of dietary vitamin E on the oxidative stability, flavor, color, and volatile profiles of refrigerated and frozen turkey breast meat. Poultry Science, 76, 634-341.

[23] Ruiz, J.A., Guerrero, L., Arnau, J., Guardia, M.D. and Esteve-García, E. (2001) Descriptive sensory analysis of meat from broilers fed diets containing vitamin $\mathrm{E}$ or $\beta$-carotene as antioxidants and different supplemental fats. Poultry Science, 80, 976-982.

[24] Salmon, R.E., Stevens, V.I., Poste, L.M., Agar, V. and Butler, G. (1988) Effect of roasting breast up or breast down and dietary canola meal on the sensory quality of turkeys. Poultry Science, 67, 680.

[25] Savage, T.F., Nakaue, H.S., Holmes Z.A. and Taylor, T.M. (1986) Feeding value of yellow peas (Pisum sativum L. Variety Miranda) in market turkeys and sensory evaluation of carcasses. Poultry Science, 65, 1383.

[26] Savage, T.F., Nakaue, H.S. and Holmes, Z.A. (1985) Effects of feeding live yeast culture on market turkey performance and cooked meat characteristics. Nutrition Reports International, 31, 695-703.

[27] Savage, T.F., Holmes, Z.A., Nilipour, A.H. and Nakaue, H.S. (1987) Evaluation of cooked breast meat from male turkeys fed diets containing varying amounts of triticale, variety flora. Poultry Science, 66, 450.

[28] Reyes, B.V., Rodríguez dela, T.M., Ramírez, R.E.J., Franco, Z.D. and Camacho-Escobar, M.A. (2009-2010) Smartketing sensorial, elemento estratégico para generar valor agregado a la meleagricultura de traspatio. Ciencias Agrícolas Informa, 19, 62-66.

[29] Poole, G.H., Lyon, C.E., Buhr, R.J., Young, L.L., Alley, A., Hess, J.B., Bilgili, S.F. and Northcutt, J.K. (1999) Evaluation of age, gender, strain, and diet on the cooked yield and shear values of broilers breast fillets. Journal of Applied Poultry Research, 8, 170-176. 